\title{
SURROGACY IN UKRAINE: THEORETICAL AND APPLIED PROBLEM
}

\section{LITERATURE REVIEW}

\section{V.S. BLIKHAR}

doctor of philosophical sciences, professor, director of the Institute of Management, Psychology and Security of the Lviv State University of Internal Affairs, Lviv

ORCID: 0000-0001-7545-9009

\section{I.M. ZHAROVSKA}

doctor of juridical sciences, professor,

Department of Theory, History and

Philosophy of the Law National

University "Lviv Polytechnic", Lviv

ORCID: 0000-0003-3821-8120

\section{N.V. ORTYNSKA}

doctor of juridical sciences, professor,

Department of Theory, History and

Philosophy of the Law National

University "Lviv Polytechnic", Lviv

ORCID: 0000-0002-5061-5340

\section{Contacts:}

Viacheslav S. Blikhar

Lviv State University of Internal Affairs

Gorodotska str. 26,

79007, Lviv, Ukraine

Tel.: +38 (097) 241-89-03

Email:blikharv@gmail.com

\section{INTRODUCTION}

Children born after assisted reproductive technologies (ART) (surrogacy) are exposed to many risks that do not leave us indifferent. There are negative precedents when children are left without parental care, despite great desire of their biological parents to take care of them. This unfortunate practice is due to many factors that underlie poor legal support of surrogacy in Ukraine and requires detailed analysis to develop a reliable legal regulation. The article considers historical aspects of the origin and formation of surrogacy and analyzes the first cases that raised the issue of children born after ART. The legislation of Ukraine on surrogacy is analyzed, and the gaps and limitations that cause the violation of the rights and interests of the participants in the surrogacy process are identified. To create quality legislation, it is necessary to study the existing international practice of resolving disputes over children born after surrogacy.

\section{METHODOLOGY}

The latest human rights in the field of the new reproductive technologies are primarily related to the synergetic approach. This is due to uncertainty and the inability to predict synergistic movement in the development of both legal relations and legislation. An interdisciplinary approach will combine knowledge of legal science and other social sciences, including medicine and biology, especially in projected development and unforeseen achievement. The method of synthesis is used in the analysis of the complexity of the subject, as theoretical and legal relations include a wide range of subjects: surrogate mother, parents-clients, health care institution, surrogate mother's husband, intermediaries, guardianship authorities, etc. Finally, of all methods used, the list of which is wide, we should mention the method of hermeneutics, which allows us to interpret the sources of law, by the way, both as regulations and court precedents. The praxiological component of the research is added by the method of sociological survey, which was conducted according to the author's questionnaires on the public position on the legalization of the method of surrogacy in Ukraine.

The purpose of this article is to investigate the aspects of theoretical and legal regulation of surrogacy in Ukraine.

\section{HISTORY OF ORIGIN AND FORMATION OF SURROGACY}

People's natural desire to have children is one of the oldest in the human history. However, the problems of infertility also have a long history, which is reflected even in biblical texts. One bright example is the story of Sarah and Abraham, who were married and could not conceive a child. Hagar gave birth to a boy who was considered a child of Abraham and Sarah. This case can be considered as surrogacy because the couple used the womb of another woman to have a child.

Similar examples can be found in the Code of Hammurabi, which describes cases of infertility in women and the possibility of using the womb of a concubine (slave) to have children. This clearly illustrates that surrogacy dates back to more than 3,800 years ago. From ancient times, the use of another's womb to conceive a child has been acceptable in the case of female infertility. The womb for rent (ventrem locare) to an infertile couple is also known in Ancient Rome. After birth, such a child was considered the child of an infertile couple, which thus confirms that surrogacy in fact has always existed, but with the evolution of mankind, the ways to conceive a child in the womb of another woman have improved.

The inventor of in vitro fertilization (IVF) is biologist Robert Edwards from the Cambridge University, who was awarded the Nobel Prize in Medicine. Robert Edwards performed IVF simulations on mice and in 1972 was ready to use the results in human reproductive biology.

Due to the research of the inventor, in 1978, in England, Louise Joy Brown became the first child in the world to have been born after conception by IVF. Her mother suffered from infertility for a long time. In 1977, she first underwent an experimental IVF procedure, which proved successful. In 1980, the first surrogacy program was held in the United States, culminating in the successful conception and birth of a healthy boy. Five years later, a successful gestational surrogacy took place - the surrogate mother had no genetic relationship with the child. The surrogate mother was paid 10,000 USD for her services.

In surrogacy, the interests of the child born after ART are the most important. In practice, there are cases when the surrogate mother, after giving birth to a child, does not want to give up the child to prospective parents. This raises a number of extremely important issues. Such 
case happened in 1986. Melissa Stern, known as "Baby M", was born in the United States via surrogacy. The child's surrogate (biological) mother refused to fulfill the contract concluded between her and the couple. "A New Jersey Court ruled that Whitehead was the child's legal mother and declared surrogacy contracts illegal and invalid. However, the court assigned custody of Melissa to the child's biological father William Stern and his wife Elizabeth Stern, and not to the surrogate mother" [18]. Unfortunately, such cases are not uncommon, which emphasizes the relevance of the issue in the surrogacy process.

A similar case occurred in 1990 and the case of Johnson v. Calvert took place in California in 1993. The surrogacy contract stated that the surrogate mother would carry the child conceived by the couple through embryo transfer, and after the childbirth, she would give up the child to the couple for a fixed fee $(10,000$ USD). Due to the misunderstandings, the parties went to court. After hearing the evidence and arguments, the trial court ruled that Mark and Crispina Calvert were the child's "genetic, biological, and natural" father and mother, and that Anna had no "parental" rights to the child, and that the surrogacy contract was legal and enforceable despite Anna's claims. The court ruled that the child's genetic parents were spouses, the mother was Ms. Calvert, and the surrogate mother did not have right to the child.

In the surrogacy process, the genetic connection of at least one parent is important to recognize the child as genetically related to the couple. Providing genetic material by a surrogate mother causes many problems related to moral, psychological, and later legal aspects [1, 13, 14, 16, 31-33]. That is why we insist on inadmissibility of involving genetic material of a surrogate mother. Today, Ukraine has become the center of surrogacy in the world. This is due to a variety of reasons that are extremely attractive to foreigners, but imperfect legislation creates many problems, which usually affect children born after surrogacy. We must always follow the best interests of the child as recognized in the national legal paradigm and the whole civilized world. However, there are still many questions to which there is no clear and simple answer. That is why it is necessary to consider comprehensively all the risks that may be encountered by the participants of the surrogacy process and to focus on children as the greatest value.

\section{LEGAL REGULATION OF SURROGACY IN UKRAINE}

Today there is no international standard for regulating this method of reproduction, so states personally determine this by national legal policy. Table shows the features of legal regulation in terms of state legislation. As we can see, the policy is ambiguous and includes both an absolute categorical prohibition and criminalization of the act, and the permissibility of all types of surrogacy. The latter is generally typical for post-Soviet states.

Today in Ukraine there is no single regulatory legal act that would comprehensively regulate legal relations under study. This is a major shortcoming that needs to be addressed immediately as the dispersion of certain norms in the legislation contributes to their ambiguous interpretation and subsequently to the abuse of their rights by the participants. In the domestic legislation, there is not even a clear definition of surrogacy. Different names for the method of ART under study, such as "substitute motherhood" and "assisted motherhood", can be found in legislative acts. We believe that a single term that could fully reflect the meaning of the process under study should be unified [10, 28, 29]. "Surrogacy is the procreative practice in which a woman gestates an embryo with which she has no biological relationship for another person, eventually relinquishing the child to the other party. This practice normally involves financial remuneration for the surrogate; when this does not occur, it is called altruistic surrogacy" [3].

In the Civil Code of Ukraine, several articles regulate the issue of ART. Art. 290 states that an adult has the right to be a donor of reproductive cells. In Art. 281 p. 7 the legislator stipulates that a woman or a man, having reached the age of majority, has the right to undergo treatment for ART programs on medical grounds. This article is a reference to the order "On Approval of the Procedure for the Use of Assisted Reproductive Technologies" No. 787 of 2013. The order explains the principles of the IVF process (namely the development and fertilization of the embryo and its transfer to the uterus), i.e. outside the woman's body. It is important to emphasize that the legislation establishes the examination procedure for a woman and a man who plan to undergo the process under study. This is an important element for the success of the process both for prospective parents and surrogate mothers as it can eliminate certain problems (contraindications) at the initial stage. It is also important that the legislator, although in the form of a recommendation, emphasizes the transfer of no more than 1, 2 embryos into the uterine cavity. This aspect is especially important given the health of the prospective mother and the ethical aspect of this multifaceted issue. The law also stipulates that "a surrogate mother must not have a direct genetic connection with the child". This rule is justified by the fact that if the surrogate mother has a genetic connection with the child, then it can be regarded as "human trafficking" punishable by criminal law and inadmissible on moral and psychological grounds.

Today in Ukraine there is an age limit for a surrogate mother: she must be an adult (18 years old). We believe that it is necessary to change this approach and raise age limit to 20 years. This is due to the fact that a person at the age of 18 is too young to make the decision to become a surrogate mother. Such decision can lead to a difficult emotional and moral process for the person, which is why raising the age limit at the legislative level is justified. Ukrainian civil law does not set an upper age limit for a woman who wants to become a surrogate mother. If in the altruistic version of using this method it may be admissible, then in the commercial version it seems that it is necessary to set an upper age limit of 40 years. We justify this upper age limit by a woman's physical ability to reproduce, which will have the negative impact on her physical health at the least. Also, it should be borne in mind that before reaching this age, the chances of having a healthy baby are higher, because after 40 years, pregnancy can provoke various diseases for the woman.

Also, the same legislation stipulates that the future surrogate mother must have her own healthy child. We believe that this requirement is somewhat exaggerated as it restricts women's right to become a surrogate mother in the absence of their own child, 


\section{ЛІКУВАННЯ НЕПЛІДНОСТІ ТА ВАГІТНІСТЬ}

Table. Peculiarities of countries'legal regulation of surrogacy

\begin{tabular}{|c|c|c|c|c|}
\hline Country & All types are allowed & Forbidden & $\begin{array}{l}\text { Only altruistic (non-commercial) } \\
\text { allowed }\end{array}$ & $\begin{array}{l}\text { There is no legal regulation, } \\
\text { although it is underway }\end{array}$ \\
\hline Austria & & + & & \\
\hline Germany & & + & & \\
\hline Norway & & + & & \\
\hline Sweden & & + & & \\
\hline France & & + & & \\
\hline Italy & & + & & \\
\hline Switzerland & & + & & \\
\hline Poland & & + & & \\
\hline Belgium & & & & + \\
\hline Ireland & & & & + \\
\hline Finland & & & & + \\
\hline Czech Republic & & & & + \\
\hline Japan & & & & + \\
\hline Australia & & & + & \\
\hline Great Britain & & & + & \\
\hline Denmark & & & + & \\
\hline Israel & & & + & \\
\hline Spain & & & + & \\
\hline Canada & & & + & \\
\hline Netherlands & & & + & \\
\hline India & & & + & \\
\hline Ukraine & + & & & \\
\hline USA & + (some states) & + (some states) & & \\
\hline Georgia & + & & & \\
\hline Russia & + & & & \\
\hline Belarus & + & & & \\
\hline Kazakhstan & + & & & \\
\hline
\end{tabular}

which may be due to not the physical ability to have children, but to social or other aspects that are related to the fourth generation of human rights (child-free family). Thus, it is necessary to change the domestic legislation on the outlined issue, which does not correspond to the modern human rights in the globalized world.

In the Marriage and Family Code of Ukraine in Art. 56, p. 3, 4 it was stated that "A man who has given written consent to the fertilization of his wife with the help of a donor is recorded as the father of the child and has no right to dispute the record. A wife who has given written consent to her husband for fertilization and giving birth to the child by another woman (donor) is recorded as the mother of the child and has no right to dispute the record". This laid the basis for a certain legal regulation of surrogacy in Ukraine [25]. General legal regulation is preserved today. The Family Code of Ukraine in Art. 123, p. 2 declares that in case of transfer of a human embryo conceived by a couple (man and woman) as a result of using ART to another woman's body, then the couple is the parents of the child. Thus, the legislator regulates the origin of the child born after surrogacy.
It should be noted that the process of fertilization involves many procedures that the future surrogate mother should know as they are associated with risks to her health.

In the Law of Ukraine "Fundamentals of Legislation of Ukraine on Health Care" in Article 48 Artificial Fertilization and Embryo Implantation" it is stated that "the use of artificial fertilization and embryo implantation is carried out on the medical grounds of an adult woman with whom such a process is being performed, subject to the written consent of the couple, ensuring the anonymity of the donor and medical confidentiality [12]. Surrogacy is also regulated by the Order of the Ministry of Health of Ukraine "On Approval of Statistical Documentation on Assisted Reproductive Technologies" No. 489 of December 10, 2001 [20].

Also, in the domestic legislation, it is established that the surrogacy program is available only to the couple in the registered marriage. We believe that such a norm does not correspond to modern approaches to the new generation of human rights. First of all, the requirement to register a marriage is exaggerated as people may live together for years and at the same 


\section{ЛІКУВАННЯ НЕПЛІДНОСТІ ТА ВАГІТНІСТЬ}

time not want to register their relationship. We also believe that a woman or a man who is single also has the right to have children through the method of surrogacy. For example, IVF of a single woman is permissible, but in case of infertility, she is doomed. That is why this legal approach needs to be changed and allow a single man or woman to use the method of surrogacy.

In foreign practice, the question arises about the use of surrogacy by same-sex couples. We believe that if a country allows the registration of marriages of such couples, then the state and society are committed to the modern understanding of the family, so the use of surrogacy is acceptable. In Ukraine at this stage, society is not yet ready to recognize the union of same-sex couples as a model of the family in modern perception, which is why now is not the time to talk about the use of surrogacy by same-sex couples.

Somatic rights are such a sensitive legal issue that it is possible to analyze it only by analyzing public sentiment and the position of civil society. To do this, we conducted a survey on the author's questionnaires. Respondents selected adult citizens of Ukraine, held in four regions of the country (Lviv, Kyiv, Odesa, Kharkiv).

On the question of approval of the current legal policy, respondents' opinions were divided almost equally, there is no general negativity of the public, but approval is also not expected. The results are shown in Figure 1.

However, regarding the permissibility of such activities for foreigners, the majority of the public considers it necessary to ban such practices. The possibility of surrogate reproduction with a foreign element is positively assessed by 126 people, against 267 negatives. The results are shown in Figure 2.

In our opinion, the issue of attitudes towards women who agree to become surrogate mothers is representative (Fig. 3). In total, 327 respondents condemn or more likely to condemn, which is $73 \%$ of respondents. This gives us reason to say that respondents have an abstract view of legal policy, but if the issue concerns a separate morally and religiously discussed concept, they become more categorical, and tend to have a negative attitude to such practices.

Due to the extremely limited legal regulation of surrogacy, special attention today needs to be paid to the surrogacy contract, which should reflect all key aspects of this legal relationship. The fate of the child and the compensation to the surrogate mother who bore the child depend on the existence of a surrogacy contract. All objective risks that may occur when using this method of ART should be noted as this will protect against subsequent lawsuits, which are unfortunately quite common today. Concluding a quality surrogacy contract is especially important for foreign citizens as this is always an additional risk

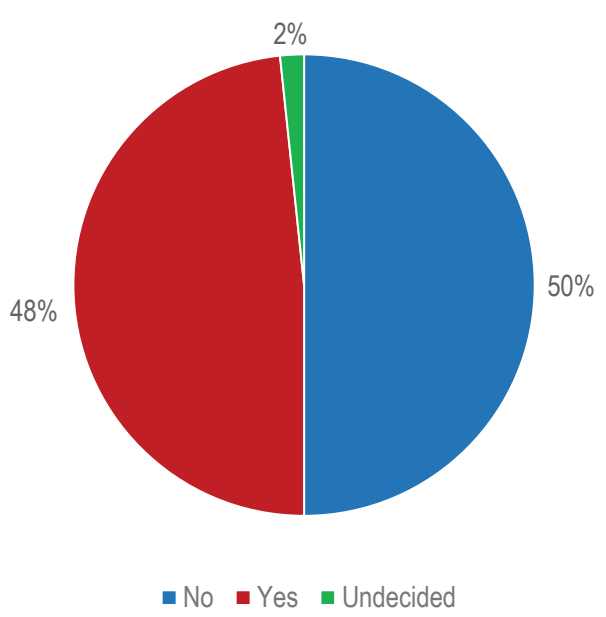

Figure 1. Do you approve of legalizing surrogacy in Ukraine?

It should be banned for foreigners $55.62 \%$

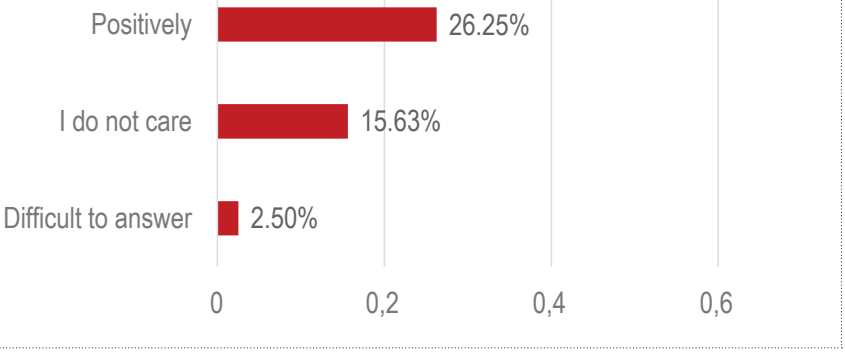

Figure 2. Ukraine has become a world center of surrogacy, what is your attitude to this?

0,6

0,5

\section{$48.75 \%$}

0,4

0,3

0.2

0,1
3



Yes

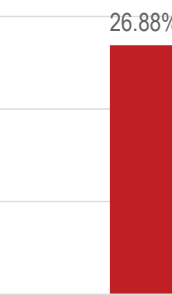

No, it's their choice

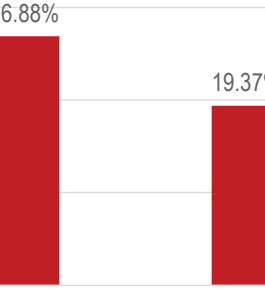

Rather, yes

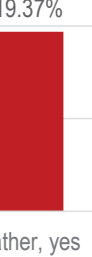

$5.00 \%$

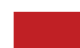

Difficult to answer
Figure 3. Do you condemn women who agree to become surrogate mothers?

in surrogacy. Therefore, in order to establish the necessary recommendations and conclusions, it is important to analyze the legal practice that exists in cases related to surrogacy.

\section{COURT PRACTICE OF RESOLVING DISPUTES \\ CONCERNING SURROGACY}

Today, surrogacy is banned in many countries. These include countries with strong Muslim traditions. In Europe, surrogacy is banned in Germany, France, Austria, Spain, Bulgaria, Luxembourg, Finland, Norway, Switzerland, Slovenia, and Sweden. 
Indeed, the Federal Court of Justice of Germany in 2019 ruled that a child born after surrogacy in Ukraine should be adopted by a couple from Germany despite the fact that in Ukraine the authorities responsible for civil registration recorded the German couple as the child's parents in the birth certificate. However, when the child was registered in Germany, a surrogate mother was recorded as the child's mother in accordance with German law. It should be emphasized that in Germany, surrogacy is classified as a crime punishable both for medical staff (doctors) and those who facilitated it. A similar situation occurs in Switzerland. It is important that the above case is a powerful precedent that can qualitatively solve the problem with children born after surrogacy.

According to some researchers, in current debates there are strong disputes whether surrogacy strengthens reproductive rights (e.g. women's right to choose, involuntarily childless people's reproductive rights, LGBTQ rights) or impedes them (e.g. surrogates' right to abortion or to keep the child) $[8,11,21$, $27,30,34,40]$. As such, the ethical and political debates on surrogacy are intrinsically intertwined not only with medical and psychological risks, but also with issues concerning autonomy, agency, and justice, as well as risks of coercion and exploitation $[4,15,17,19,22,37,38]$. Moreover, the laws regulating surrogacy differ widely between countries $[5,6,23,35,39]$.

Unfortunately, in world practice, there are cases when a child having three mothers is left with none. This is a situation called Baby Manji that happened in 2008. The Japanese couple signed a contract with an Indian surrogate mother. The man had a genetic relationship with the child and an anonymous woman was the egg donor. A month before the baby was born, the couple divorced and despite the fact that the husband wanted to take the child, the ex-wife was against it. It was impossible to determine the child's citizenship and parenthood because as a genetic father, a man could adopt a child, but under Japanese law, a single man had no right to adopt a girl, and under Indian law, a mother is considered the one who have given birth. So, being between two legal systems, there was a real paradox that was difficult to solve. Following trials in the Supreme Court of India, custody of the child was given to the mother of the biological father. As the problem of commercial surrogacy was not regulated at the legislative level at that time, it became the subject of discussion by Indian legal experts [24], which clearly demonstrates the problems that exist in the issue under study.

The Constitutional Court of Portugal has rightly noted that today the focus on the exclusive protection of women (surrogate mothers) has somewhat shifted, despite the same set of rights that are the most important and must be protected, and for which the state has a special obligation - to protect the rights of the child. In a deeply individualistic world, where an increasingly utilitarian and hedonistic conception of a person is easily recognized by science and medicine, it is important to remember that scientific evolution does not stem from a simple individual and selfish interest, but rather a public interest aimed at creating better conditions for humanity. It does not seek to restrain the achieved progress, which is also an achievement for humanity, but simply to ensure that the momentum of identifying and overcoming barriers does not break the particular weighing of values that in their individual and collective dimensions constitute the essence of a person. The Court emphasizes the way in which the best interests of the child are secured in the event of:

- a conflict which has led to a breach of contract;

- in decisions to terminate pregnancy;

- refusal to give up the child;

- (iv) refusal to accept the child after birth;

- death of the beneficiaries before the child's birth [36].

We believe that in order to address the outlined problems that exist in Ukraine, there should be an organization that will control and monitor the use of surrogacy ART, which already exists in some countries around the world. Such organization would be analyzing the grounds for the process itself and monitoring the fulfillment of the terms of the contract between the prospective parents and the surrogate mother and, most importantly, the future of the child born through this method. After all, today the lack of quality state supervision over such process has given rise to unlawful intermediary firms that create extremely harsh conditions for surrogate mothers during childbearing. Also, it should be noted that in commercial surrogacy, there is a high chance of pressure on a surrogate mother, who is vulnerable, as women often resort to such activity due to lack of money, which is frequent in our country.

The European Court of Human Rights heard the case of "Mennesson v. France" and "Labassee v. France" in 2014 on the registration of children born through surrogacy as in that case, they would acquire French citizenship. Non-recognition of the children's status at the same time worsens their position on inheritance, obtaining a French passport, and access to educational services. The court concluded that France had thereby violated respect for privacy [18].

In 2019, such precedents again took place in the European Court of Human Rights in the form of an advisory opinion. From the Court's case history, it follows that Article 8 of the Convention requires that domestic law offers the possibility of recognizing the connection between the child born after surrogacy abroad and the biological parent. In the Mennesson case, the Court directly concluded that the absence of such possibility violated the child's right to respect for privacy that is guaranteed by this provision. That is, the Court notes that its judicial practice today puts an emphasis on the existence of a biological connection between the child and at least one of the designated parents [2].

The Court of Cassation of France in 2019 also concluded that any act of civil status of French and foreigners drawn up in a foreign country in the forms used in that country is authentic. Exceptions include other existing documents or when the documents, external data, or elements of the act itself after all necessary checks establish that the act is irregular, falsified, or that the facts stated in it are not true. In all decisions concerning children, whether taken by public or private social welfare institutions, courts, administrative authorities, or legislative bodies, the best interests of the child shall be entitled to a primary consideration [7].

Therefore, in countries where surrogacy is banned, the authorities must proceed from these principles, which are emphasized by the European Court, in order to protect the best interests of the child and not to violate the Convention, which 
is especially important in today's conditions when surrogacy has developed. After all, it should be noted that the processes of legal recognition of the child are quite long, which also negatively affects the legal status of the child. Today, the coronavirus pandemic has become an unexpected problem for children born through surrogacy, as the country has closed its borders, thus blocking the possibility for foreign parents to pick up their newborn babies. In May alone, more than 100 children were expecting their parents from abroad in various reproductive medicine centers. Thus, such a large number of children born through surrogacy is primarily a sign of the huge demand for these services in Ukraine, which is the basis for revising the legal paradigm of the legal relationship under study, making appropriate changes in current legislation, and creating appropriate conditions for implementing this assistive technology taking into account the best interests of the child and complying with all obligations of the parties in this legal relationship [27]. Indeed, the pandemic has caused many problems for which we were not prepared, which is why today we must accumulate all the legal capacity to overcome the existing problems.

\section{CONCLUSIONS}

The lack of specialized regulations causes the possibility of abuse of rights or even criminal acts. Any participant of legal relations in the field of surrogacy can become a subject of fraudulent schemes. Moreover, there are no adequate social and legal guarantees in national or international law for the protection and safeguarding of the parties of surrogate legal relations. Currently, these relations are regulated by contract, but in a system where the normative act dominates, such a provision is unacceptable. We in no way encourage or tend to oppose the method of surrogacy. However, the lack of regulation, if in reality these relations receive practical application, is unacceptable. The problem of infertility is not new. This worries people and pushes them for its solution. Surrogacy has been there since biblical times and helped couples feel the joy of parenthood. Evolution and progress in the medical field have allowed people to have a biologically native child through surrogacy. Today, Ukrainian legislation cannot fully provide for this institution and needs significant improvement, and the aspect that our state has become a center of surrogacy only emphasized the importance of legislative changes. Judicial practice related to surrogacy stands upon the best interests of the child, but legal proceedings take years underlying the need to develop certain international rules on the fate of a child born through surrogacy. Due to the global pandemic, access to justice has undergone a negative impact, which is reflected on people's lives. That is why today it is important to create the best conditions to protect the best interests of children born through surrogacy.

Judicial practice related to surrogacy stands upon the best interests of the child, but legal proceedings take years underlying the need to develop. In general, a survey of the Ukrainian public indicates that they do not approve of this reproductive method, have a negative attitude towards women who agree to become surrogate mothers, and consider it necessary to ban foreigners from using this method in Ukraine. We believe that it is still necessary, albeit post factum, to hold public discussions on this issue, if the national legislator considers it necessary to maintain legalizing legislation.

\section{REFERENCES/ЛІTЕPATУPA}

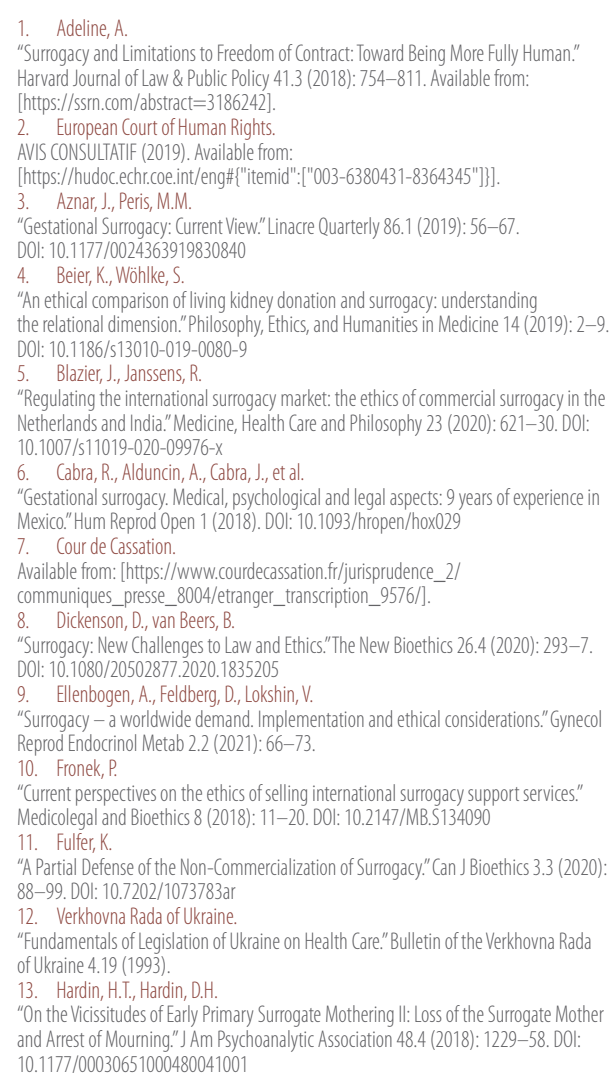

14. Hevia, M.

"Surrogacy, Privacy, and the American Convention on Human Rights." J Law Biosci 5.2 (2018): 375-97.DOl: 10.1093//lb/lsy013 Jouan, $M$.

"The moral acceptability of surrogacy: Using what can be learned from pregnancy for oneself to achieve greater justice."Travail, genre et sociétés 38 (2017): 35-52. D01: $10.3917 / \operatorname{tgs} .038 .0035$

16. Konečná, H. Svatoš, R.

"Issues in determining parenthood in"surrogacy"'." Human Affairs 29.2 (2019): 129-44. DOl: 10.1515/humaff-2019-0011

Lambda, N., Jadva, V., Kadam, K., Golombok, S.

"The psychological well-being and prenatal bonding of gestational surrogates." Human

Reprod 33.4 (2018): 646-53. D0l: 10.1093/humrep/dey048

18. Mennesson v. France and Labassee v. France:

Surrogate motherhood across borders. Available from:

[https://strasbourgobservers.com/2014/07/16/

mennesson-v-france-and-labassee-v-france-surrogate-motherhood-across-borders/]

9. Mitra, S., Schicktanz, S.

Failed surrogate conceptions: social and ethical aspects of preconception disruptions during commercial surrogacy in India." Philosophy, Ethics, and Humanities in Medicine (2016): 2-16. Dol: 10.1186/s13010-016-0040-6

20. Ministry of Health of Ukraine

Order from 10.12.2001. No 489"On Approval of Statistical Documentation on Assisted

Reproductive Technologies." (registered with the Ministry of Justice of Ukraine on

25.10.2001, № 1068/6259). Available from:

[http://zakon2.rada.gov.ua/laws/show/z1068-01].

21. Oultram, S.

"One mum too few: maternal status in host surrogate motherhood arrangements"

J Medical Ethics 41 (2015): 431-2. D0l: 10.1136/medethics-2015-102879

22. Patel, N.H., Jadeja,Y..., Bhadarka, H.K., et al.

"Insight into Different Aspects of Surrogacy Practices."J Hum Reprod Sci 11.3 (2018):

212-8. DOI: 10.4103/jhr.J.JHS $138 \quad 17$

23. Payne, JG Korolczuk E Mezinska, S

"Surrogacy relationships: a critical interpretative review." Ups J Med Sci 125.2 (2020):

183-91. D01: 10.1080/03009734.2020.1725935

24. Points, K.

"Commercial surrogacy and fertility tourism in India: The Case of Baby Manji."The Kenan Institute for Ethics at Duke University. Available from:

[https://web.duke.edu/kenanethics/casestudies/babymani..pdf].

Reznik, 0.M., Yakushchenko, Y.M.

"Legal considerations surrounding surrogacy in Ukraine."Wiadomości Lekarskie LXXIII.5 (2020): 1048-52.

Saadeh, R., Abdulrahim, N., Alfagih, M., Khader, Y.

"Attitude of Jordanian Health Care Workers Toward Surrogacy." Jamily Reprod Health 14.1

(2020): 5-13.
27. Shchyrska, V., Konopelskyi, V., Popovych, Y., et al.

"Ethical and Legal Aspects of Surrogacy in Ukraine and in the World." J Legal, Ethical and Regulatory Issues 23.2 (2020). Available from: [https://www.abacademies.org/journals/ month-april-year-2020-vol-23-issue-2-journal-ileri-past-issue.html].

28. Simopoulou, M. Sfakianoudis, K., Tsioulou, P., et al.

"Risks in Surrogacy Considering the Embryo: From the Preimplantation to the Gestational and Neonatal Period." BioMed Research Int (2018). DOl: 10.1155/2018/6287507

29. Simopoulou, M., Sfakianoudis, K., Rapani, A., et al.

"Considerations Regarding Embryo Culture Conditions: From Media to Epigenetics." In Vivo 32.3 (2018): 451-60. DOl: 10.21873/invivo.11261

30. Straehle $C$

"Is there a right to surrogacy?" J Applied Philosophy 33.2 (2016): 146-59.

DOl: $10.1111 /$ japp. 12145

31. Stuvøy, I.

"Troublesome reproduction: surrogacy under scrutiny." Reprod Biomed Soc Online 7

(2018): 33-43. DOl: 10.1016/j.rbms.2018.10.015

32. Swanson, K., Ayala, N.K. Barnes, R.B., et al.

"Understanding gestational surrogacy in the United States: a primer for obstetricians and gynecologists."Am J Obstet Gynecol 222.4 (2020):330-7.

DOl: 10.1016/.j.jog. 2020.01.037

301: 10.1016/j.ajog.2020.01.037

Surrogacy: An international comparative analysis of the fundamental legislative principles

of Ukraine." Medicine, Science and the Law 60.1 (2019): 37-44.

DOI: $10.1177 / 0025802419884417$

34. Tan 5.

"Surrogacy and human flourishing." Jegal Philosophy 45.1 (2020): 49-79.

DOI: $10.4337 /$ /ilp. 2020.01 .03

35. Torres, G., Shapiro, A., Mackey, T.K.

A review of surrogate motherhood regulation in south American countries: pointing to a

need for an international legal framework." BMC Pregnancy Childbirth 19 (2019): 2-12

DOl: $10.1186 / 512884-019-2182-1$

36. Tribunal Constitucional Portugal.

ACÓRDÃO N $0225 / 2018$ Avalable from:

[http://www.tribunalconstitucional.pt/tc/acordaos/20180225.html].

7. Ullah, A., Nawaz, F.

"Surrogacy-led migration: reflections on the policy dilemmas. Public Administration and Policy:

An Asia-Pacific Joumal 23.2 (2020): 157-71. DOl: 10.1108/PAP-03-2020-0014

38. Valsamakis, G., Chrousos, G., Mastorakos, G.

"Stress, female reproduction and pregnancy." Psychoneuroendocrinology 100 (2019):

48-57. D01: 10.1016/ipsynewen. 2018.09 .031

9. Verkerk, M., Lindemann, H.Mclauglin,

9. Verkerk, M., Lindemann, H., McLaughlin, J., et a. .

Where families and healthcare meet."J Med Ethics 41.2 (2015): 183-5.

DOl: 10.1136/medethics-2013-10178

40. Zaouaq, $K$.

"La gestation pour autrui au regard de l'éthique et du droit." Can J Bioethics 3.3 (2020): 128-33. DO|: 10.7202/1073789ar 


\section{ЛІКУВАННЯ НЕПЛІДНОСТІ ТА ВАГІТНІСТЬ}

\section{SURROGACY IN UKRAINE: THEORETICAL AND APPLIED PROBLEM}

\section{Literature review}

V.S. Blikhar, doctor of philosophical sciences, professor, director of the Institute of Management, Psychology and Security of the Lviv State University of Internal Affairs, Lviv

I.M. Zharovska, doctor of juridical sciences, professor, Department of Theory, History and Philosophy of the Law National University"Lviv Polytechnic", Lviv

N.V. Ortynska, doctor of juridical sciences, professor, Department of Theory, History and Philosophy of the Law National University“ "Lviv Polytechnic", Lviv

The article analyzes the Ukrainian experience of carrying out the procedure of surrogacy.

The modern world does not stand still constant progress in all spheres of human activity has given rise to a large number of new rights that have entered the fourth generation of human rights. Surrogacy belongs to the newest generation of human rights, despite the fact that it has a long history of its origin and development, which can be traced back to biblical texts, the laws of King Hammurabi and others. The use of another woman's womb was acceptable for couples who could not conceive their own child. It clearly illustrates the existence of surrogacy, which has more than 3,800 years.

The article analyzes the progressive development of modern technology of IVF, which has opened new opportunities for humanity in case of infertility to have biologically native children. The main problems that exist in the research institute, which are related to each participant of the procedure, are highlighted. The analysis of foreign judicial practice is carried out, which allows to form certain conclusions that will have practical application in domestic realities. The legal regulation of surrogacy is considered, the need to change the age requirement for a surrogate mother and the requirements for the presence of a native child for the future surrogate mother are emphasized. Today, this institution is of particular importance to humanity, as there are many cases of infertility among couples who want to have a child and surrogacy becomes the only chance for them to have a biologically native child.

The urgency of the outlined topic is intensified due to the fact that Ukraine has become a real center of surrogacy due to the availability of the procedure and loyal legislation, which allows for an altruistic and commercial form of its conduct. However, the low level of regulation of surrogacy has had a negative impact at all stages of the procedure and needs immediate improvement in order to preserve the interests of each participant, but above all, the child born with this method of assisted reproductive technology. The importance of all the issues outlined is also intensified in connection with the coronavirus pandemic, which has brought many problems into the research institute.

Keywords: surrogacy, assisted reproductive technologies, fourth generation of human rights.

\section{СУРОГАТНЕ МАТЕРИНСТВО В УКРАЇНН: ТЕОРЕТИКО-ПРИКЛАДНА ПРОБЛЕМА Огляд літератури}

В.С. Бліхар, д. філос. н., професор, директор Інституту управління, психології та безпеки Львівського державного університету внутрішніх справ, м. Львів

І.М. Жаровська, д. юрид. Н., професор кафедри теорії, історії та філософії права Національного університету «Львівська політехніка», м. Львів

Н.В. Ортинська, д. юрид. Н., професор кафедри теорії, історії та філософії права Національного університету «Львівська політехніка», м. Львів

Стаття аналізує український досвід проведення процедури сурогатного материнства.

Сучасний світ не стоїть на місці, постійний прогрес у всіх царинах людської діяльності породив велику кількість новітніх прав, що увійшли до четвертого покоління прав людини. Сурогатне материнство належить до новітнього покоління прав людини, попри те що має довгу історію свого зародження та розвитку, що можна простежити ще з біблійних текстів, законів царя Хаммурапі та ін. Використання лона чужої жінки було прийнятним для пар, які не могли зачати власну дитину, що яскраво ілюструє існування сурогатного материнства, яке налічує понад 3800 років.

У статті проаналізовано поступальний розвиток сучасної технології екстракорпорального запліднення, що відкрив нові можливості для людства в разі безпліддя мати біологічно рідних дітей. Висвітлено основні проблеми, які існують у досліджуваному інституті сурогатного материнства та пов'язані з кожним учасником процедури. Проведено аналіз іноземної судової практики, що дозволяє сформувати певні висновки, які матимуть практичне застосування у вітчизняних реаліях. Розглянуто правове регулювання сурогатного материнства, акцентовано на необхідності зміни вікового цензу для сурогатної матері та вимоги щодо наявності рідної дитини для майбутньої сурогатної матері.

Сьогодні цей інститут має особливу значущість для людства, оскільки існує велика кількість випадків безпліддя у пар, які бажають мати дітей, і сурогатне материнство стаєє єдиним шансом для них мати біологічно рідну дитину. Актуальність окресленої тематики посилюеться з огляду на те, що Україна стала справжнім центром сурогатного материнства завдяки доступності проведення процедури та лояльному законодавству, яке дозволяє альтруїстичний та комерційний вид ії проведення. Проте низький рівень регулювання сурогатного материнства негативно позначився на всіх етапах проведення процедури та потребує негайного вдосконалення задля збереження інтересів кожного ї̈ учасника, але насамперед дитини, народженої за допомогою цього методу допоміжної репродуктивної технології. Також важливість усіх окреслених питань інтенсифікується через пандемію коронавірусу, яка внесла багато проблем у досліджуваний інститут.

Ключові слова: сурогатне материнство, допоміжні репродуктивні технології, четверте покоління прав людини.

\section{СУРРОГАТНОЕ МАТЕРИНСТВО В УКРАИНЕ: ТЕОРЕТИКО-ПРИКЛАДНАЯ ПРОБЛЕМА \\ Обзор литературы}

В.С. Блихарь, д. филос. Н., профессор, директор Института управления, психологии и безопасности Львовского государственного университета внутренних дел, г. Львов И.М. Жаровская, д. юрид. Н., профессор кафедры теории, истории и философии права Национального университета «Львовская политехника», г. Львов Н.В. Ортинская, Д. юрид. Н., профессор кафедры теории, истории и философии права Национального университета «Львовская политехника», г. Львов

Статья анализирует опыт проведения процедуры суррогатного материнства.

Современный мир не стоит на месте, постоянный прогресс во всех сферах человеческой деятельности породил множество новейших прав, вошедших в четвертое поколение прав человека. Суррогатное материнство относится к новейшему поколению прав человека, несмотря на то что имеет долгую историю своего зарождения и развития, что можно проследить еще из библейских текстов, законов царя Хаммурапи и пр. Использование лона чужой женщины было приемлемым для пар, которые не могли зачать собственного ребенка, что ярко иллюстрирует существование суррогатного материнства, насчитывающего более 3800 лет.

В статье проанализировано поступательное развитие современной технологии экстракорпорального оплодотворения, открывшее новые возможности для человечества в случае бесплодия иметь биологически родных детей. Освещены основные проблемы, существующие в исследуемом институте суррогатного материнства, которые связаны с каждым участником процедуры. Проведен анализ иностранной судебной практики, который позволяет сформировать определенные выводы, имеющие практическое применение в отечественных реалиях. Рассмотрено правовое регулирование суррогатного материнства, акцентировано на необходимости изменения возрастного ценза для суррогатной матери и требования относительно наличия родного ребенка для будущей суррогатной матери.

Сегодня этот институт имеет особую значимость для человечества, поскольку существует большое количество случаев бесплодия у пар, желающих иметь детей, и суррогатное материнство становится единственным шансом для них иметь биологически родного ребенка. Актуальность данной тематики усиливается в связи с тем, что Украина стала настоящим центром суррогатного материнства по причине доступности проведения процедуры и лояльного законодательства, позволяющего альтруистический и коммерческий вид ее проведения. Однако низкий уровень регулирования суррогатного материнства отрицательно отразился на всех этапах проведения процедуры и требует немедленного усовершенствования для сохранения интересов каждого ее участника, но прежде всего - ребенка, рожденного с помощью этого метода вспомогательной репродуктивной технологии. Также важность всех обозначенных вопросов интенсифицируется в связи с пандемией коронавируса, которая внесла много проблем в изучаемый институт.

Ключевые слова: суррогатное материнство, вспомогательные репродуктивные технологии, четвертое поколение прав человека. 